\title{
Analize in problemi prostorskega razvoja za planiranje omrežij družbene in gospodarske infrastrukture na ravni države
}

\section{Evropska unija Poselitev Slovenija Transport Urbana omrežja}

Najpomembnejši programi Evropske unije zadevajo transportne mreže, bolj natančno europsko mrežo železnic velikih hitrosti in hitrih prog ter reorganizacijo letalskih transportov. V območju severnega dela EU smo tako priča intenzivnemu planiranju, projektiranju in gradnji osnov, ki povezujejo relacije mobilnosti obsežnih teritorialnih bazenov in internacionalnih destinacij in ki usmerjajo promet tudi globalnih ekonomij. Ta izhodišča so osnova za analizo opredelitev potreb pri usmerjanju strategije prostorskega razvoja Slovenije ter razumevanja prostorskih razvojnih problemov pred oblikovanjem prioritet.

\section{European Union Settlements Slovenia Transport Urban networks}

Transport networks are the most important programmes of the European Union, more precisely, the network of fast railroads and the reorganisation of air traffic. In the North european area we are thus witness to intensive planning, design and postioning corner stones, that connect raletions of mobility between expansive territorial basins and international destinations, as well as directing transport between global economies. These starting points are the basis for analysing defined needs in directing strategic spatial development in Slovenia and understanding spatial development problems in establishing priorities.

\section{Uvod}

Vprašanje omrežij je prav v središču problematik EU (termin omrežje je v tem prispevku uporabljan v infrastrukturnem pomenu). Vprašanje je aktualno, saj se dotika temelja prostorske politike EU - integracije. Želimo ali ne, to vprašanje nas usodno zadeva, saj lahko ignoriranje tega vprašanja pripelje Slovenijo v periferni položaj. Lahkomiselni smo, če mislimo, da se nam ponujajo priložnosti, povezane s poglavitno smerjo ekonomije EU - vzhodom. Zanašanje zgolj na tako premiso lahko pogojuje razvoj v smeri države na koridorju.

Najpomembnejši programi EU zadevajo transportne mreže, bolj natančno evropsko mrežo železnic velikih hitrosti in hitrih prog ter reorganizacijo letalskih transportov. V primeru evropske mreže železnic velikih hitrosti in hitrih prog je predvidena gostota mrež srednje Evrope, neprimerljiva s tisto, predvideno $\mathrm{v}$ frankofonskonemških regijah. Dodatno slabo okoliščino predstavlja odprto vprašanje navezave - priklopa Slovenije na evropsko mrežo železnic velikih hitrosti in hitrih prog. V primeru letališč pa celo ne obstaja niti strukturna politika.

V območju severnega dela EU smo priča intenzivnemu planiranju, projektiranju in gradnji osnov, ki povezujejo relacije mobilnosti obsežnih teritorialnih bazenov in internacionalnih destinacij in ki usmerjajo promet tudi glo- balnih ekonomij. Na teh temah Slovenija prav gotovo zelo zaostaja in še vedno skuša dohiteti zamude pri izgradnji omejenih koščkov monomodalnih mrež brez jasne celostne strategije. To se nam lahko maščuje, saj projekti EU ponujajo pomembne perspektive Sloveniji: velike hitrosti in mrežo koridorjev.

Za Slovenijo je nujno najprej narediti prostorski plan države, $\mathrm{v}$ katerem bi konkretizirali politiko spodbujanja sinergij mrež vzdolž smeri vzhod-zahod, kakor tudi sever-jug, ki v medsebojnem součinkovanju sestavljajo enoten sistem blagovnega in potniškega transporta ter primernih podlag povezav: centralne postaje, letališča, pristanišča, vmesne postaje, trgovske centre. Pri tem nikakor ne smemo pozabiti na pomembne potenciale kombinacije med železniškim in pomorskim transportom, kar je za Slovenijo ključnega pomena.

Že ta bežen globalni (eksistenčni) pogled na Slovenijo, uokvirjen $\mathrm{v}$ proces evropske integracije, narekuje interpretacijo razvoja transportnih mrež kot logističnega pogoja za kakršenkoli razvoj. Kako je in kako bo naše infrastrukturno omrežje vpeto $\mathrm{v}$ evropsko, je odvisno tudi od drugih sistemov in njihovih mrež. Od posameznih kakovostnih potencialov je odvisna tudi strateška opredelitev platforme multimodalne povezanosti različnih mrež. Tem analizam in problemom je namenjen pričujoči tekst. 


\section{Analize}

\subsection{Poselitveni sistem}

Demografska stagnacija

Število prebivalcev Slovenije je po drugi svetovni vojni hitro naraščalo predvsem zaradi priseljevanja iz nekdanjih jugoslovanskih republik (Slovenija je imela pozitivni migracijski saldo po letu 1957). Tudi zato je bilo število živorojenih otrok relativno zelo veliko in je vse do konca sedemdesetih let presegalo število 30.000 letno. Velike demografske spremembe v Sloveniji lahko približno omejimo na dve letnici. Leta 1980 se je začelo hitro zniževati število rojstev, ki se še do danes ni ustavilo in se sedaj giba že samo okoli 18 000. Zaradi političnih sprememb pa se je ustavilo tudi priseljevanje in v letu 1990 je imela Slovenija po dolgih letih zopet negativni prebivalstveni migracijski saldo (Jakoš, 1999).

\section{Razpršenost poselitve}

$Z$ vidika teritorialne ureditve države je v razmerju do demografske stagnacije presenetljiva prisotnost razširjenega fenomena razpršenosti. Prebivalstvo in aktivnosti se vedno bolj dekoncentrirajo in pri tem izrabljajo mrežo osnovnih, skoraj uniformno porazdeljenih servisov. Te trditve, povzete iz študij, ki jih je naročil UPP, žal ni mogoče trdneje argumentirati zaradi pomanjkljivega instrumentarija za preučevanje tega fenomena. Tukaj gre v prvi vrsti za razmejitev naselij in njihovih pripadajočih vplivnih območij, kjer bi lahko registrirali migracijski saldo $\mathrm{v}$ razmerju med mestom in regijo oziroma ostalimi naselji in območji v regiji. Na ta način bi lahko merili stopnjo centripetalnosti migracijskih teženj celotnega območja regije. Pri tem bi lahko bili poglavitni kazalci: rast prebivalstva, migracijski saldo, migracije znotraj regije, stavbno premoženje, indeks staranja. Ključna podatka sta dinamika odseljevanja prebivalstva in distribucija dejavnosti. Pri slednjem gre za procese, ki so razširjeni zlasti v sektorju servisov, trgovini in obrti.
Približek ponujajo podatki Urbanističnega inštituta RS. V sistemu poselitve so se pokazale posledice migracijskih sprememb zadnjih dveh desetletij (ali celo nekaj več). Največji centralni kraji v Sloveniji so naraščali predvsem na račun zunanjih migracij. Ko se je ta tok priselitev ustavil, se je ustavila tudi rast prebivalstva teh krajev. To velja še zlasti za tiste centralne kraje, ki niso imeli dovolj razvitih terciarnih in kvartarnih funkcij. Izjemo predstavlja le Ljubljana, ki je dobila status državne prestolnice in s tem tudi kopico novih funkcij, s tem pa tudi delovnih mest. V zadnjem času v Sloveniji najhitreje narašča število prebivalcev $\mathrm{V}$ manjših lokalnih razvojnih centrih, ki formalno pogosto ne dosegajo niti ranga občinskih središč. Številna večja mesta v Sloveniji že zaostajajo za povprečno rastjo števila prebivalcev (Jakoš, 1999).

Fenomen razpršenosti je takšen, da ga ni mogoče enostavno interpretirati kot decentralizacijo ali fiziološko redistribucijo aktivnosti in bivališč. Zato se zastavlja vprašanje, ali so še dopustni vedno večji stroški organizacije in upravljanja mreže uslug (oskrba $z$ vodo in njeno čiščenje, oskrba s plinom, transport, odpadki) in drugih javnih servisov (socialnih, podpornih, kulturnih) ter negativni vplivi na okolje in naravne vire. Gre za fenomen, ki prekaša tradicionalno pojmovano decentralizacijo. Ocenjena progresivna rast velja tako za socialne stroške kot tudi individualne stroške (čas potovanj, cena uslug itn.). Za ponazoritev stanja je dobrodošla tudi analiza zaposlitev po občinah. Popisni podatki o številu delovnih mest $\mathrm{v}$ družbenem sektorju kažejo na veliko koncentracijo delovnih mest, ki je bistveno višja od koncentracije prebivalstva, zato prevladujejo občine s primanjkljajem delovnih mest. Primanjkljaj je še posebej izrazit v občinah blizu večjih zaposlitvenih središč, čeprav imajo te občine relativno veliko delovnih mest. Izrazito izstopa predvsem Ljubljana in tudi ostala regionalna središča. Glede na sektorje dejavnosti prevladuje primarni sektor v subpanonski Sloveniji, sekundarni sek- 
tor $\mathrm{v}$ tradicionalnih industrijskih območjih, terciarni in kvartarni sektor pa v večjih središčih. Zopet izstopata predvsem Prekmurje in na splošno vzhodna Slovenija, kjer je zelo malo delovnih mest $v$ terciarnem in kvartarnem sektorju (Gosar, 1995). S temi podatki si lahko predstavljamo težo problema zaposlitvene mobilnosti in prometa, ki ga povzroča.

\section{Vuroki razpršene poselitve}

Vzroki, ki pogojujejo določen način distribucije poselitve, so številni in pogosto kontradiktorni: za podjetja so to manjši stroški nastanitve, boljša dostopnost in večja funkcionalnost prostorov za produkcijske aktivnosti; prebivalci pa iščejo boljšo kakovost bivanja, ki je v vzročni povezavi s tako imenovanim antropološkim sindromom po avtonomnem in ne kolektivnem prostoru, manjše gradbene ali stanovanjske stroške in boljšo razpoložljivost uslug. Kot vidimo, ne obstajajo neposredne povezave med logiko naselitve podjetij in tisto, ki vodi individualno naselitveno izbiro, čeprav obe učinkujeta kot multiplikatorja razmerij mobilnosti, še posebej zato, ker so razmerja med prebivališči in delovnimi mesti v okviru regije spontana. Pokazatelji spreminjanja razmer v regiji bi bili razmerje med odstotkom povečanja stavbnih zemljišč za bivanje in terciarne dejavnosti v regiji in tudi med regionalnimi središči.

Regionalna središča so pri tem nekakšni motorji razpršitve, saj povečujejo ekstenzivnost urbanih relacij predvsem zaradi zasedanja tako imenovanega urbaniziranega podeželja za vedno nova območja nastanitve in proizvodnjo.

Začetek prostorske "difuzije" razvoja lahko iščemo v sistemu družbenega planiranja na nacionalni in lokalni ravni (brez vmesne ravni planiranja) in njeni doktrini komunalne samozadostnosti in teritorialne enakomernosti. Proces se do današnjih dni ni ustavil.

V obdobju od sprejetja Dolgoročnega plana SR Slovenije za ob- dobje od leta 1986 do leta 2000 je bila Slovenija deležna posebno močnega vpliva dveh teženj:

- umeščanja gospodarskih dejavnosti in prebivalstva $\mathrm{v}$ širše okolje regionalnih središč, in to v ekstenzivni obliki;

- centralizacije specializiranih funkcij in posebnih uslug $\mathrm{v}$ poglavitna središča, še zlasti v Ljubljano.

\subsection{Urbani sistem}

Teritorialna razmerja, prikazana skozi migracijske tokove, distribucijo mest zaposlitve in spremembe v mestih naselitve, kažejo na povečanje števila relacij med občinami. Toda večina občin še vedno ne načrtuje množice potencialnih relacij s sosednjimi občinami in tudi regionalnimi središči. Izjema je območje ljubljanske regije. Relacije so zelo poenostavljene in gredo $\mathrm{v}$ smeri državno središče-makro regionalno središče-občinsko središče in nazaj. Zato je mogoče izslediti nekaj tokov, ki se glede na intenzivnost (merjeni skozi recipročne relacije) ločijo po "entropičnem" temelju in ki lahko izražajo strukturo regije. Pri tem je veliko vprašanje, ali sploh gre za urbano poselitveno strukturo Slovenije, saj ponujajoča se množica relacij ni infrastrukturno podkrepljena.

\section{Razmerja med središči}

Pri analizi vloge in pomena regionalnih središč je upoštevana teritorialna razdelitev Slovenije na tri makroregije in 12 tako imenovanih statističnih regij. Pri tem so regionalna središča pojmovana kot primarni generatorji ekonomskih in socialnih razmerij celotnega teritorija regije.

Gledano regionalno so bila $z$ izjemo posavske, notranjske in zasavske regije okoli regionalnih središč formirana bolj ali manj prostrana zaledja, ki pa se praviloma raztezajo vzdolž glavnih prometnih koridorjev in okoliških grebenov. Zahvaljujoč spremenjenemu geostrateškemu položaju, je po osamosvojitvi Slovenije prišlo do 
sprememb v pomenu nekaterih poglavitnih središč in do sprememb $\mathrm{v}$ intenzivnosti nekaterih razmerij. Tako se, gledano makroregionalno, na ravni države oblikujejo naslednja makroregionalna središča: Maribor, Ljubljana, Koper, pri tem pa je Koper glede na svojo velikost še vedno $v$ inferiornem položaju. Poleg tega se zdi, da Koper nima posebej poudarjenih regionalnih relacij. Odnosi $z$ okolico so še vedno slabotni in omejeni, medtem ko Trst povečuje in intenzivira svoj vpliv v okoliških občinah, tudi na našem ozemlju, po logiki oblikovanja vencev središč nižjega ranga okoli regionalnega središča. Koper kot makroregionalno središče ni uspel integrirati niti tradicionalnega razmerja med Izolo in Piranom, ki bi ga lahko oblikoval v linearno mesto, še manj pa nove (radialne) smeri proti zaledju in drugim sosednjim regionalnim središčem, še zlasti proti Gorici in Reki. Zato pa je Ljubljana spletla celotno regijo $\mathrm{V}$ svoje gravitacijsko torišče $z$ izredno intenzivnostjo relacij, tudi na račun središč nižjega ranga. Fenomen je bolj čitljiv, če ga opazujemo regionalno. Prav Kranj, z mikavno konkurenco Ljubljane, izgublja intenzivnost svojih relacij.

Tudi v okolici Maribora se je oblikovala skupina občin, ki sestavljajo njegovo zaledje, vendar so razmerja manj intenzivna kot $\mathrm{v}$ ljubljanski regiji. Mariborski makroregiji se pozna pomanjkanje še enega popolnega regionalnega središča, kot je Celje. Zato je policentrična struktura območja štajerske makroregije slabotna in pod močnimi tenzijami Zagreba in Gradca.

\section{Razmerja med tolcovi}

Uveljavljajo se aktualni trendi $\mathrm{v}$ oblikovanju razmerij med tokovi, ki predpostavljajo nove urbane sisteme različnih stopenj, torej zunaj tradicionalnih regionalnih središč. Območja regionalnih središč so oblikovala močna razmerja vzdolž razpoložljivih smeri gričevnatega sveta in vzdolž smeri, ki jo imenujemo prometni križ, vendar s pomanjkljivimi radialni- mi relacijami, ki so nujne za transformacijo teh $\mathrm{v}$ bolj urbana središča. Zato so na splošno prisotna binarna razmerja. Obstajajo območja različnih obsegov, različnih intenzivnosti razmerij in $z$ različnim urbanim značajem: od izrazito močne in prostrane okolice Ljubljane in gričevnatega sveta Novega mesta do slabotnejše in manj obsežne hribovite okolice Slovenj Gradca ...

Zunaj teh smeri so prepoznavni drugačni sistemi razmerij, ki lahko odražajo obstoj podrejenih urbanih sistemov. Občine v območju ljubljanske regije vzdržujejo močna medsebojna razmerja vzdolž smeri prometnega križa in, kjer to dovoljujejo fiziografski pogoji, v radialnih smereh, kar ustvarja pogoje za zametke urbanih subcentrov tipa Domžal. To velja manj za Maribor in, kot smo videli, Koper. Celje pa bo po dograditvi avtocestnega sistema, čeprav je danes sestavni del mariborske makroregije, predstavljalo most med ljubljansko in mariborsko makroregijo, kar kaže na možnost nastanka nove makroregije. Poudarjeno vlogo Celja v urbanem sistemu lahko vidimo tudi v povezavah $\mathrm{z}$ Novim mestom, saj so bile takšne ideje že prisotne oziroma so se obravnavale zgolj kot hipoteza.

Kakorkoli, med makroregionalnimi teritoriji obstajajo že danes značilna tripolarna razmerja, katerim podrejeno vsebino predstavljajo razmerja produktivne, stanovanjske in funkcionalne narave. $\mathrm{V}$ ostanku Slovenije, zlasti zunaj prometnega križa, kot v severnoprimorski, koroški, zasavski pa tudi morebitni novi kočevski regiji, so naselja še vedno oropana razmerij interurbanega značaja.

\subsection{Teritorialni sistemi}

$\mathrm{V}$ evropskih regijah veliki teritorialni elementi, kot so: mesta, podeželje, hribovje in obalno območje, progresivno izgubljajo svojo avtonomijo sorazmerno $z$ večanjem intenzivnosti relacij. Pokazatelji, ki govorijo $\mathrm{v}$ korist temu, so: rast razpršenosti in tekmovalnosti, 
Dostop do mrež vrhunskih funkcij se zdi poglaviten za določitev vloge Ljubljane $\mathrm{v}$ metropolitanskem policentričnem regionalnem sistemu oziroma definira zmožnosti in meje metropolitanskega mesta. Morebitna določitev Ljubljane kot metropolitanskega mesta odpira možnost učinkovite izvedbe prostorskega plana in $\mathrm{v}$ okviru tega tudi izvedbo hierarhično opredeljenega policentričnega sistema poselitve. To pa so zaenkrat le predpostavke, saj Slovenija še vedno nima sprejete resolucije o prostorskem razvoju države.

Prav ta naj bi poleg izpostavljanja in reševanja prostorskih problemov podala možnosti rabe vseh specifičnih potencialov urbanega regionalnega sistema. Šele v tem kontekstu je mogoče predpostavljati vlogo in pomen regionalnih središč in izdelati strategije regionalnega razvoja.

Pred našo skupnost se zato postavlja kontekstualni problem natančne definicije funkcij središč, ki sestavljajo regionalni sistem in tudi opredelitev povezav med posameznimi območji makroregionalne, regionalne in mikroregionalne ravni. S tem bi dokončno opustili prakso sektorskih politik nizkega redistribucijskega profila in se osredotočili na izboljšanje kakovosti planov urbanih območij, ki so danes neprimerni za povezovanje vseh implicitnih sinergij v potencialnem razvoju regij.

\section{Vloge ostalih središč}

Zamujanje pri odpiranju številnih panog ekonomskih aktivnosti evropskemu in svetovnemu trgu povzroča zamude pri specializaciji in sodelovanju tako gospodarskih panog kot posledično tudi samih mest. Prej navedeni pokazatelji teženj pa nam lahko nakažejo "smeri razvoja" integracij in povečevanje medsebojnih razmerij. Katera mesta je potrebno tesneje medsebojno povezati $\mathrm{z}$ ustreznim rangom infrastrukture? Katera območja rastejo $\mathrm{v}$ tesnem odnosu Z makroregionalnimi strukturami? Katera območja zaradi svoje monousmerjenosti je nujno pre- kategorizirati? Katera območja izražajo višji položaj posebnih funkcij? Katera območja intenzivirajo ustvarjanje delovnih mest?

Tudi v teh vprašanjih, na katera stroka še ni odgovorila in si jih ni niti zastavila, lahko iščemo zamude v skoraj vseh mestih pri izdelavi prostorskih planov, ki bi prednostno, zaradi višje stopnje specializacije in posledično večjega obsega medsebojnega sodelovanja, povečevali število medsebojnih razmerij in drugih oblik integracij. To še zlasti velja za makroregionalna središča, ki so $\mathrm{v}$ tesnem odnosu s prestolnico. Situacijo do neke mere rešuje izdelava avtocestnega križa, ki poleg makroregionalnih zasleduje tudi regionalne in lokalne probleme, če ga opazujemo skozi število avtocestnih priključkov. Seveda pa ob tem povzroča že omenjene probleme razpršenosti.

Ljubljana že postaja poglavitna točka uslug za vso državo. Zlasti izstopa koncentracija veletrgovin. $\mathrm{Ob}$ tem se ruši tradicionalna samozadostnost industrijskih območij, kar najbolj očitno zasledimo na primeru zasavske regije. To pa postavlja pod vprašaj tudi nominalni obstoj same regije (statistične). Gledano makroregionalno obstaja velika nevarnost, da čaka podobna usoda vso Slovenijo, v kolikor je ne bomo sposobni umestiti med globalne produkcijske mreže. S prostorskega vidika in vidika vzpostavitve novih razmerij $z$ Ljubljano si utrjuje Maribor višji položaj posebnih funkcij, kot je na primer univerza, pri tem pa ne uspe intenzivirati ustvarjanja novih delovnih mest, kar mu jemlje moč pri zmožnosti dialoga z Ljubljano.

Ne glede na zamude $\mathrm{v}$ prostorskem vidiku razvoja pa posamezne panoge sledijo globalizacijskim trendom. Izobraževalni sektor se decentralizira: šola managerstva na Brdu pri Kranju in druge ustanove usposabljanja zunaj okvira univerze $z$ zadovoljivimi rezultati na ravni količine vpisov in $z$ dobrimi učinki na lokalna okolja; širjenje aktivnosti mariborske univerze; rast pomena sejemskih 
ustanov širom Slovenije; tem trendom sledijo tudi zasebne zdravstvene ustanove. Po drugi strani pa tradicionalna regionalna gledališča pestijo finančni problemi, ne da bi začenjala sodelovati za izboljšanje uslug in zmanjšanje stroškov upravljanja. Javne zdravstvene strukture pa se še niso začele uglaševati na regionalni ravni tako, da bi uskladile svoje usluge $\mathrm{z}$ zahtevami uporabnikov in skrajšale čakalno dobo za specialistične usluge.

Za mesto je torej pomembna pravilna lega znotraj mreže ravnomerno porazdeljenih potencialov (tudi krajinskih), v kolikor poseduje vozlišča mrež, ki povezujejo najbolj pomembne trge evropskih centrov in $\mathrm{v}$ kolikor mesto predstavlja sedež specializiranih funkcij, relativno avtonomnih glede na urbani kontekst. Govorimo namreč o poglavitnem inovativnem potencialu. Gre za razširjanje mreže enakih potencialov, skladno $\mathrm{z}$ aktiviranjem resursev $\mathrm{v}$ širšem okolju in v tistih krajih, v katerih se ponujajo specializirani organizirani resursi ali potencialna možnost njihove organizacije, kot na primer: neposredne investicije, pritegnitev podjetij ali raba lokalnih naravnih ali kulturnih danosti. Tak položaj in organizacija mesta vzpostavljata pogoje urbanega blagostanja.

Uvajanje aktivnosti na lokalno raven s pomočjo globalnega delovanja pa ni tako avtomatično oziroma samoumevno. Sicer pa je tudi res, da njihovo uvajanje ne deluje nujno kot lokalni spodbujevalec proizvodnje in komplementarnih uslug. Kakorkoli, kazalec neposrednih tujih vlaganj je izrazito neugoden in eden najmanjših $\mathrm{v}$ državah "tranzicije".

Pri tem niso samo vrhunske funkcije tiste, zaradi katerih metropolitansko območje označujemo kot primarni dobavitelj globalnih mrež za opredelitev vloge in ranga določenega mesta, temveč sta bolj gostota in kompleksnost funkcij tista, zaradi katerih to mesto predstavlja primarni sovpad med lokalno in globalno ravnijo.

\section{Problemi}

\subsection{Prebivalstvo}

Prebivalstvo, ki se progresivno stara hkrati z šibkimi imigracijskimi tokovi, postavlja na preizkušnjo mrežo uslug, funkcionalnost in učinkovitost socialne politike. Tudi v bodoče je prebivalstvu Slovenije usojeno zmanjševanje njegovega števila in stopnjevanje socialnih transferjev. Na trgu delovne sile se pojavljajo tako kvalificirani subjekti za najbolj propulzivne aktivnosti, kot tisti $z$ najnižjo kvalifikacijo. V kolikor bi $\mathrm{v}$ naslednjih desetletjih rodnost in umrljivost ostala na sedanji ravni, razlika med številom priseljenih in odseljenih pa bi bila nič, bi število prebivalcev Slovenije počasi naraščalo še do leta 2003, nato pa bi se začelo vedno hitreje zniževati. Čez dvesto let bi nas bilo samo še dobrih štiristo tisoč, ali za malo večjo Ljubljano. Nizka rodnost pa ne pomeni samo nižanja števila prebivalcev, ampak tudi velike spremembe $\mathrm{v}$ starostni sestavi prebivalstva. Tako se zelo hitro znižuje delež mlajšega prebivalstva in zato nekoliko kasneje tudi delež za delo sposobnega prebivalstva. Zelo hitro pa narašča delež starejšega prebivalstva. Leta 1991 je bilo v Sloveniji $10,9 \%$ vsega prebivalstva starejšega od 65 let, ta delež pa bi se po predvidevanjih po letu 2040 povzpel že prek 20 \% (Jakoš, 1999).

Številne usluge bodo morale biti zato reorganizirane in premišljene zaradi demografskih in socialnih sprememb in glede na različna območja: ljubljanska regija $z$ največjo dinamiko, obmejna območja Slovenije $z$ izrazito regresijo.

\subsection{Stroški razpršene poselitve}

Kljub temu, da so v dolgoročnem planu upoštevani procesi razpršene poselitve in da je načrtovano "umeščanje v prostor" predvsem v regionalna središča, se ti nadaljujejo. Pri vsem tem se v konkretni administrativni praksi ta plan ne izvaja. Zdi se, kot da dolgoročni plan na ta naraščajoči proces ni- 
ma vpliva. Vsaka občina je napihovala lastno porabo zemljišč z evidentiranjem tako imenovanih "potreb po prostoru". Prestiž in identiteta občine sta temeljila na rasti prebivalstva in delovnih mest. Iskanje vedno novih razpoložljivih zemljišč za znanega investitorja je bila prioritetna naloga vsake administracije, kar je v nasprotju $z$ "dobro" občinsko politiko, ki naj bi ponujala zazidljiva zemljišča za neznane investitorje. In tako je še danes.

Posledica aktualnih zemljiških politik je predimenzioniranost in slaba izkoriščenost zazidalnih površin. Za primerjavo porabita Nizozemska in Danska $\mathrm{v}$ povprečju 4,5-krat manj zemljišč za vsakega novega prebivalca, kot jih porabimo v Sloveniji (Dekleva, 1998). Glede na odsotnost ponudbe komunalno opremljenih stavbnih zemljišč - razen kar zadeva ponudbo zasebnikov - in veliko povpraševanje je logično, da so se zasebni investitorji prisiljeni "znajti".

Lokacijsko gledano pa se podjetja in prebivalci logično distribuirajo $\mathrm{v}$ teritoriju regije ali občine, saj izrabljajo prisotnost mreže uslug (ceste, tehnološke mreže, javni servisi), ki so skoraj enakomerno porazdeljene in dobro locirane $\mathrm{v}$ centralnih krajih.

Dosedanji stroški nastanitve $\mathrm{v}$ lastni režiji so bili zelo nizki, saj pri tem niso bili zajeti predvsem stroški za okolje, zlasti ko gre za ireversibilne spremembe. S tem mislimo na spremembe $\mathrm{v}$ rabi in zaščiti tal, krajini, zlasti agrarni in gričevnati v slabšalnem pomenu. Gre za probleme nizke urbane kakovosti novih naselij, odvoz komunalnih odpadkov in probleme varstva voda.

Tem se pridružujejo ekonomski stroški zajamčene teritorialne enakosti distribucije uslug. Temu principu sledi režim splošnega obdavčevanja in socializacije stroškov. Času primerno pa bi bilo nujno imeti drugačen režim, pretežno osredotočen na razločnost tarif različnih meril in breme uporabnikov. V razmerju do de- mografskih kazalcev in nujnega povečanja kompetitivnosti regij in občin v procesu približevanja EU pa izgradnja mrež za distribucijo vode in energije, mrež za odvod odpadnih voda, objektov za čiščenje in odlaganje, zbiranje komunalnih odpadkov, nujnih socialnih uslug (šol, zdravstvenih služb, drugih oblik pomoči) ne bo mogla več slediti kakršnikoli obliki teritorialne distribucije poselitve. V nasprotju s tem bomo prisiljeni vedno bolj upoštevati združevanje naložb in vzdržnost mreže uslug. Sedanji sistem fragmentacije je nujno treba preseči s povezovanjem, reorganizacijo in celovitostjo pristopov.

\subsection{Kriza javnega prevoza}

V zadnjih 10-ih letih se progresivno zmanjšuje raba javnega in narašča raba zasebnega prevoza, kar je neizogibna posledica rasti teritorialne mobilnosti oseb in trgovine. Razpršena oblika poselitve onemogoča vsaj minimalne pogoje funkcionalnosti in dostopnosti $z$ javnimi oblikami prevoza.

Ekonomska razmerja so se diverzificirala in multiplicirala. Prebivalstvo in delovna mesta so $\mathrm{v}$ teritoriju regij čedalje bolj razpršena. $\mathrm{V}$ takšnih pogojih ni več možno jamčiti minimalno konkurenčnega servisa javnega prevoza, vsaj ne brez ogromnih stroškov in ekskluzivno vzdolž radiocentričnih smeri do centralnih krajev. V lanskem letu smo bili priča krčenju voznega reda vlakov.

Posledično je prometni problem eksplodiral v vseh makroregionalnih središčih oziroma v poglavitnih prometnih ciljih. Kakšni so, posledično, mestni - socialni in zasebni stroški prevozov, ne vemo.

Investicije $\mathrm{v}$ ceste so skočile na prvo mesto na seznamu javnih investicij. V preteklih letih si nekateri na občinski ravni prizadevajo zgraditi obvoznice okoli središč in s tem povečati propustnost regionalnih cest. Ob tem, da nismo niti na sredini izvedbe avtocestnega programa. Nasprotno pa se v že- 
lezniškem prometu dela malo in zgolj z najemanjem dragih posojil. Reorganizacija s ciljem izboljšanja rezultatov poslovanja poteka na račun lokalnega prevoza.

\subsection{Vprašanje bivanja}

Visoke cene nepremičnin, majhna razpoložljivost primernih stanovanj in visoke najemnine $\mathrm{v}$ mestih so povzročile beg prebivalcev iz mest in jih usmerile $\mathrm{v}$ iskanje cenejše rešitve stanovanjskega problema.

Neurejenost "trga" nepremičnin sproža razpršenost vedenja prebivalcev in podjetnikov. Temu asistirajo novi davki (komunalni prispevki), davki na premoženje in rast cen nepremičnin. Do sedaj so investitorji igrali na karto dvigovanja vrednosti nepremičnin in $\mathrm{s}$ tem povezanim manjšim obsegom stanovanjske gradnje, ne glede na lokacijo stanovanj. Temu je botrovala odsotnost rente. Pri tem se še ni povečala razpoložljivost stanovanj, povpraševanje za nakup nepremičnin še ni upadlo. Poglaviten problem urbanih območij pa je, kako zagotoviti večjo ponudbo najemnih stanovanj za razumne stanarine. Te so $\mathrm{v}$ vsakem primeru previsoke za socialno šibke plasti.

\subsection{Vprašanje mest}

V sistemu družbenega planiranja je bilo osnovno vodilo komunalna samozadostnost oziroma kako omogočiti vsakemu občinskemu območju, da popolnoma razvije svojo vlogo znotraj policentričnega sistema. Posledično je prišlo do podvajanj dejavnosti in nepotrebne zasedbe obsežnih zemljišč. Tako je imela na primer skoraj vsaka od bivših občin lastno deponijo odpadkov.

Dolgoročni plan je predvideval nujno krepitev mest oziroma regionalnih središč znotraj regionalnega sistema. Tako imenovani "razvoj" pa je potekal v smeri vse večje moči občinskih središč. $\mathrm{Pi}$ salo se je tudi o hitrejšem tehno- loškem razvoju, višji ravni storitev, skratka o dvigu ravni funkcij sistemov v razmerju do regionalnega sistema mest. Ugotavljamo prạv nasprotno: relativno izgubo identitete mest in njihovih teritorijev, ki je vezana na nezmožnost valorizacije resursov in lokalnih zmožnosti, nujnih za zagotovitev ekonomskega uspeha, ter prekinitev komunikacij med družbo in administracijo.

Trenutno pa se nahajamo v položaju, ko bi se mesta v odnosu lokalno/globalno morala reorganizirati in dvigniti konkurenčnost ter kakovost svojega delovanja, krepitev mest pa temeljiti na enakovrednih pogojih in ne več na enakovredni distribuciji resursov razvoja. V nasprotju s tem pa lokalna okolja niso niti na stopnji prepoznavanja lastnih resursov in spodbujanja tekmovalnosti. Zgolj sprejeti obstoječo prostorsko strukturo in evolutivne spontane trende, podedovane iz preteklosti, več ne zadostuje. Ocena je, da gre pri reševanju aktualnih problemov bolj za dvig kakovosti obstoječih procesov, ki so že prisotni v različnih regionalnih območjih, kot pa za inovativne procese.

Vsako mesto živi od komplementarnosti razmerij s svojim teritorijem; s strukturiranimi odnosi, ki so osnove za servise in specializacije. To je osnovni pogoj za oblikovanje popularno imenovanih mrežnih razmerij, pri katerih ni pomembno imeti vse in tudi kar ni mogoče. Mnogo bolj učinkovito je biti dobro povezan $\mathrm{z}$ infrastrukturo kot imeti vse na lastnem teritoriju.

\subsection{Vprašanje planiranja}

Z Dolgoročnim planom Slovenije se namerava preseči nediferencirane politike poselitve, uslug in struktur, da bi podprli višjo identiteto krajev na podlagi logike relativne (zmerne) koncentracije v subregionalnih centrih. Prostorski plan pa je istočasno in v diametralnem nasprotju predpostavil kulturno spremembo in $\mathrm{v}$ pod- 
stati vsebino komunalnega programa. Te vsebine so danes tukaj in prevladujoče. Vprašanje je, $\mathrm{v}$ kolikšni meri je ta divergentnost plana prispevala $\mathrm{k}$ razkošnemu programiranju oskrbe, kar je v veliki meri oviralo temeljni koncept regionalnega programiranja in kar se v svoji opredelitvi ohranja še danes.

$\mathrm{V}$ procesu približevanja EU in nujnega povečanja konkurenčnosti Slovenije kot regije postajajo vidiki razpršenosti vedno bolj pereči. Sedaj prinaša razpršenost le stroške, ki se nevzdržno podvajajo in, čeprav se odlagajo na kasnejši termin, probleme le še potencirajo. $\mathrm{V}$ tem kontekstu narašča nujnost nekega "reda $\mathrm{V}$ razmerjih", neke racionalnosti, ki vodi v organizacijo uslug, mobilnosti, rabo urbanih prostorov in okolja, k integraciji funkcij in odnosov med poglavitnimi funkcija$\mathrm{mi}$ in mesti. Element trga nezadržno vstopa v organizacijo uslug in nas sili $k$ racionalizaciji, zmanjševanju stroškov in optimiziranju upravnih območij ter izboljšanju uslug, če to želimo ali ne. Neprijetno, zlasti za tiste, ki živijo bolj oddaljeni od naselij, je da bodo kot uporabniki vedno bolj poklicani pokriti realne stroške uslug neposredno skozi tarife in ne zgolj posredno skozi davčne odtegljaje.

Mag. Peter Gulič, univ. dipl. inž. ur. kraj., Urad RS za prostorsko planiranje, Ministrstvo za okolje in prostor

Viri:

Dekleva, Jože: Pregled instrumentov prostorske regulacije, Povzetek raziskovalnega projekta. Projektna skupina za pripravo strategije trajnostnega razvoja mesta Ljubljane, Ljubljana 1998.

Dolgoročni plan SR Slovenije za obdobje od leta 1986 do leta 2000. Uradni list SRS, št. 1/86, 41/87, $12 / 89$ in Uradni list RS, št. 36/90, 27/95, 13/96 - kartografski del, 11/ 99, Ljubljana.

Družbeni plan Socialistične republike Slovenije za obdobje 1981-1985. (1981) Uradni list SRS, št. 12-729/ 81, Ljubljana.
Gosar, Lojze: Regionalni in urbani sistemi Slovenije. Urbanistični inštitut RS, Končno poročilo, Ljubljana 1995.

Jakoš, Aleksander: Kazalci prostorskega razvoja na državni in regionalni ravni: Ocena obstoječega stanja in prostorsko razvojne možnosti RS in posameznih regij RS, Vsebinski sklop: Ocena obstoječega stanja in prostorsko razvojne možnosti RS in posameznih regij RS glede na kazalce regionalnega razvoja. Urbanistični inštitut RS, 2a faza: Regionalni razvoj omrežij, Ljubljana 1999.

Lenarčič, Leonid: Strukturni koncepti prostorskega razvoja Republike Slovenije. Urbanistični inštitut RS, Zaključno gradivo, faza II/3, II/4, II/5 in II/6, Ljubljana 1996.

Lenarčič, Leonid: Kazalci prostorskega razvoja na državni in regionalni ravni: Ocena obstoječega stanja in prostorsko razvojne možnosti RS in posameznih regij RS, Vsebinski sklop: Ocena obstoječega stanja in prostorsko razvojne možnosti RS in posameznih regij RS glede na kazalce prostorskega razvoja sistemov. Urbanistični inštitut RS, 2b faza: Prostorski razvoj omrežij, Ljubljana 1999.

Mihevc, Pavel: Tipologija homogenih območij (novih občin) Slovenije, Urbanistični inštitut RS, Ljubljana 1993.

Ocena dejavnosti urejanja prostora, planskega stanja in stanja v prostoru Republike Slovenije (korigirana delovna verzija), Republika Slovenija, Ministrstvo za okolje in prostor, Urad RS za prostorsko planiranje, Ljubljana 1999.

Odlok o obvezni enotni metodologiji in obveznih enotnih kazalcih, ki so potrebni za pripravljanje, sprejemanje in uresničevanje planov samoupravnih organizacij in skupnosti ter družbenopolitičnih skupnosti, Uradni list SRS, št. 27/79, Ljubljana 1979.

Popis prebivalcev in stanovanj 1991, Republika Slovenija, Vlada Republike Slovenije, Urad RS za statistiko, Ljubljana 1991.

Resolucija o prostorski razvojni politiki Republike Slovenije (Delovni osnutek), Republika Slovenija, Ministrstvo za okolje in prostor, Urad RS za prostorsko planiranje, Ljubljana 1998.

Statistični letopis Slovenije, Vlada Republike Slovenije, Urad RS za statistiko, Ljubljana 1998.

Strokovne podlage za strategijo prostorskega razvoja, Urad RS za prostorsko planiranje, Ljubljana 1996. 